\title{
Extensive Left Iliac Veins and Inferior Vena Cava Thrombosis Revealing a Giant Uterine Myoma
}

\author{
ANA CĂRBUNARU ${ }^{1}$, V. HERLEA ${ }^{2}$, M. IONESCU ${ }^{1}$, T. DUMITRAȘCU ${ }^{1}$ \\ ${ }^{1}$ Center of General Surgery and Liver Transplant \\ ${ }^{2}$ Department of Pathology, "Fundeni”" Clinical Institute, Fundeni Street no. 258, 022328, Bucharest, Romania
}

\begin{abstract}
A deep vein thrombosis was rarely associated with uterine myomas. Hereby, it is presented the case of a 40-year-old woman in which the clinical manifestation of the deep vein thrombosis revealed the further diagnosis of a large uterine myoma. The diagnosis, management and clinical outcome of the patient are emphasized and discussed. The management of a patient with a uterine myoma and deep vein thrombosis is challenging and implies a multidisciplinary team.
\end{abstract}

Key words: uterine myoma; deep vein thrombosis; inferior vena cava filter; anticoagulation.

\section{INTRODUCTION}

Uterine myomas are benign tumors and represent the most common pelvic tumors in women [1-3].

An association of a deep vein thrombosis with a uterine myoma has been previously described $[4,5]$, but few patients presented extensive thrombosis $[6,7]$.

Hereby, it is presented the case of a patient in which the clinical manifestation of the deep vein thrombosis revealed the further diagnosis of a large uterine myoma.

\section{CASE REPORT}

A 40-year-old non-smoking woman, gravida 0 , with no history of oral contraceptives, presented with important swelling of the left lower limb. An intentional weight loss in the last 3 months was noticed (current body mass index of $25 \mathrm{~kg} / \mathrm{m}^{2}$, from initially $31 \mathrm{~kg} / \mathrm{m}^{2}$ ). The weight loss was due to diet and sports. Furthermore, no risk factors for a venous thrombosis could be identified at the anamnesis. The clinical onset was observed 3 weeks prior to the presentation.

Clinical examination revealed edema of the left lower limb, with tenderness at palpation, a Homans' positive sign, and a large pelvi-abdominal mass reaching the umbilicus.
Laboratory findings revealed mild anemia (hemoglobin $9.7 \mathrm{~g} / \mathrm{dL}$; normal ranges: $11.5-17 \mathrm{~g} / \mathrm{dL}$ ) and thrombocytosis (platelet count $516000 / \mathrm{mm}^{3}$; normal ranges: $\left.150000-400000 / \mathrm{mm}^{3}\right)$. D - dimers were within normal ranges. No thrombophilia abnormalities were detected (protein $\mathrm{C}$ and $\mathrm{S}$, antithrombin, factor V Leiden).

A contrast-enhanced computed tomography revealed a large tumor mass of the lower abdomen and pelvis $(15.3 / 26.7 / 25 \mathrm{~cm})$, originating from the uterine wall, with an important compressive effect on the surrounding organs (hydronephrosis and deviation of the urinary bladder). Furthermore, thrombosis of the inferior vena cava, the common, internal and external left iliac veins and the left femoral vein were observed (Figure 1). A Doppler flow ultrasonography confirmed an acute deep venous thrombosis of the above-mentioned veins.

An anticoagulant therapy with low molecular weight heparin (i.e., Fraxiparine 7500 UI twice a day) was started.

A total hysterectomy with bilateral adnexectomy was performed 2 weeks after inferior vena cava filter placement.

Gross examination of the operative specimen revealed a large uterus distorted with a 25/21/ $20 \mathrm{~cm}$ gray-white, firm tumor. The uterine weight was $4500 \mathrm{~g}$. The microscopic examination revealed a benign leiomyoma. Within the tumor, hyaline degeneration was observed (Figure 2).

The postoperative outcome was uneventful, and the patient was discharged on postoperative day 7 . 


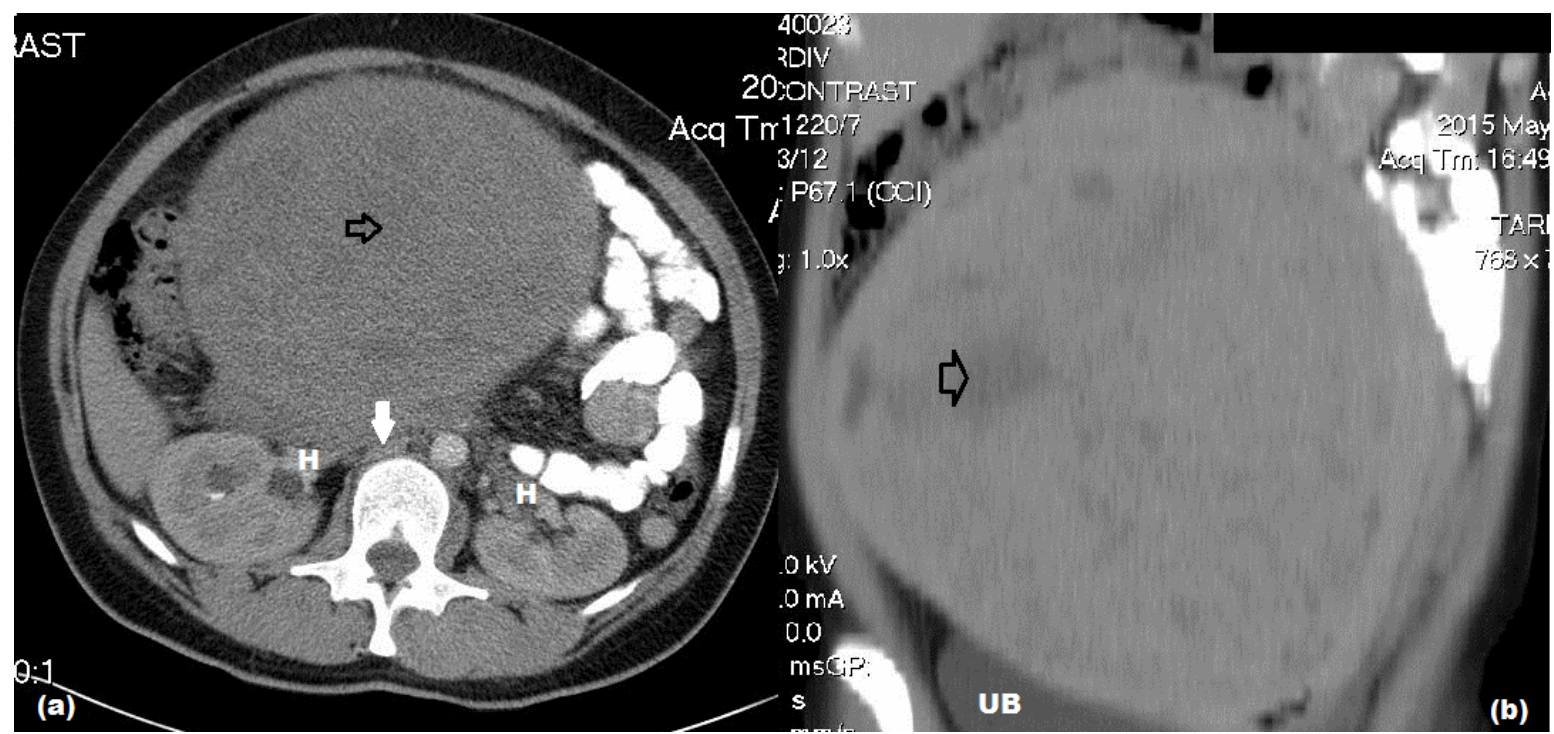

Figure 1. Contrast-enhanced computed tomography showing a giant abdominopelvic soft tissue mass with (a) associated hydronephrosis $(\mathrm{H})$ and inferior vena cava thrombus (white arrow) and (b) compression of the urinary bladder (UB) (the black arrow marks a hypodense area corresponding to a hyaline degeneration).

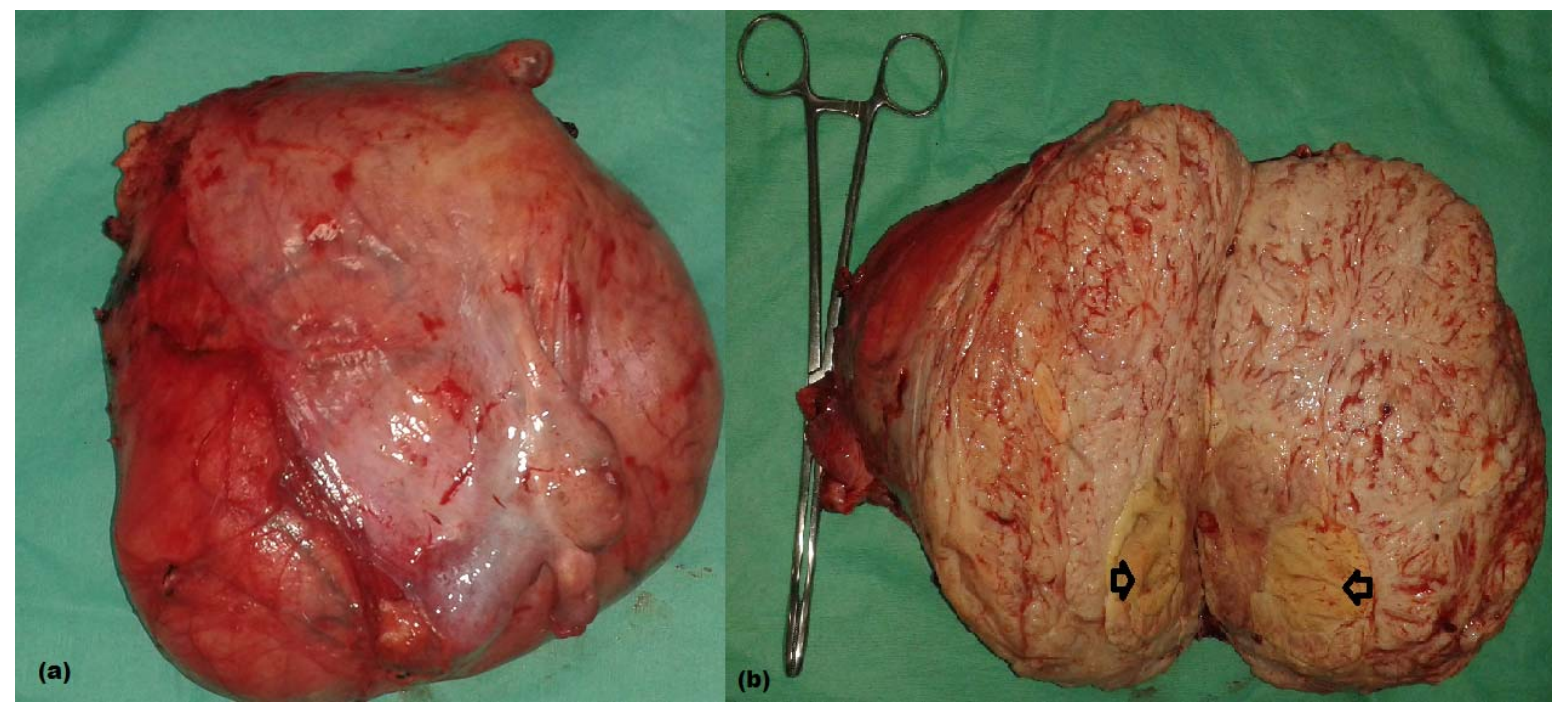

Figure 2. Gross appearance of a large uterine myoma: the operative specimen of total hysterectomy with adnexectomy (a); on the transected specimen it is shown the area of hyaline degeneration (black arrows) (b).

\section{DISCUSSION}

There are a limited number of references that connect the presence of a large uterine myoma with a venous thrombosis [4-6, 8-15]. A number of 67 patients were described up to 2014 , with a mean age of 45 years, and with the left lower limb veins thrombosis predominance [4-6, 8-15].

The management of a patient with a uterine myoma and deep vein thrombosis is challenging and implies a multidisciplinary team [1]. The main objectives of the treatment are deep vein thrombosis treatment, prevention of the pulmonary embolism and removal of the uterine myoma.
Immediately after the diagnosis is established, an anticoagulation therapy (usually with low molecular weight heparins) should be started [1].

A deep vein thrombosis in a patient with a uterine myoma is most likely due to compression of the pelvic veins with secondary stasis, and this particular clinical situation is an absolute indication for hysterectomy [1] because the obstructing mechanism is removed [6]. An intravenous leiomyomatosis and anemia induced by hemorrhages could be also involved in the thrombosis mechanism [4, 16]. Anemia may potentially induce a hypercoagulable state due to reactive thrombocytosis [17]. 
Intraoperative removal of a large tumor may potentially lead to dislodgements of the thrombi and, thus, to increase the risk of a pulmonary embolism [1]. Thus, a preoperative inferior vena cava filter mount should be taken into consideration in a subset of patients with a uterine myoma and extensive deep vein thrombosis, with the aim to prevent a potentially fatal pulmonary embolism [18].

In the reported patient, the deep vein thrombosis could be explained by the compression induced by the large tumor mass, but it also may be related to the reactive thrombocytosis, secondary to anemia. The decision to place a temporary inferior vena cava filter was taken considering the extensive deep vein thrombosis, the presence of thrombi into the proximal inferior vena cava and the high risk to mobilize thrombi during the surgical manipulation of the tumor.

\section{CONCLUSION}

The management of a patient with a uterine myoma and deep vein thrombosis is challenging and implies a multidisciplinary team. An inferior vena cava filter placement prior to hysterectomy may potentially reduce the risk of a pulmonary embolism due to dislodgements of the thrombi during the intraoperative tumor manipulation.

Conflict of interest: none.

Tromboza venoasă profundă este rar întâlnită în fibroamele uterine. Prezentăm cazul unei paciente de 40 de ani, la care semnele clinice de tromboză venoasă profundă au condus la stabilirea diagnosticului de fibrom uterin gigant. Diagnosticul, atitudinea terapeutică şi rezultatele sunt puse în evidență. Managementul unei paciente cu fibrom uterin şi tromboză venoasă profundă este dificil necesitând cooperare multidisciplinară.

Correspondence to: Traian Dumitraşcu, Center of General Surgery and Liver Transplant,

"Fundeni" Clinical Institute, Fundeni Street no 258, 022328, Bucharest, Romania,

Phone/Fax: +40 21318 0417,

E-mail: traian.dumitrascu76@gmail.com

\section{REFERENCES}

1. GUPTA S, MANYONDA IT. Acute complications of fibroids. Best Pract Res Clin Obstet Gynaecol 2009; 23:609-617.

2. STEWART EA. Clinical practice. Uterine fibroids. N Engl J Med 2015; 372:1646-1655.

3. VILOS GA, ALLAIRE C, LABERGE PY, LEYLAND N, VILOS AG, MURJI A, et al. The management of uterine leiomyomas. J Obstet Gynaecol Can 2015; 37:157-181.

4. RIAT R, CHOWDARY P, MAVRIDES E, MAGOS A, GATT A. Is there an association between thrombosis and fibroids? A single centre experience and literature review. Int J Lab Hematol 2013; 35:e13-e16.

5. SHIOTA M, KOTANI Y, UMEMOTO M, TOBIUME T, TSURITANI M, SHIMAOKA M, et al: Deep-vein thrombosis is associated with large uterine fibroids. Tohoku J Exp Med 2011; 224:87-89.

6. HUFFMAN-DRACHT HB, COATES WC. Uterine leiomyomata-related thromboembolic disease: A case report. J Emerg Med 2010; 39:e101-e104.

7. TANAKA H, UMEKAWA T, KIKUKAWA T, NAKAMURA M, TOYODA N. Venous thromboembolic diseases associated with uterine myomas diagnosed before hysterectomy: a report of two cases. J Obstet Gynaecol Res 2002; 28:300-303.

8. CUI X, PEKER D, GREER HO, CONNER MG, NOVAK L. Extramedullary hematopoiesis in uterine leiomyoma associated with numerous intravascular thrombi. Case Rep Pathol 2014; 2014:957395.

9. FERNANDES FL, DINARDO CL, TERRA-FILHO M. Uterine myoma as a cause of iliac vein thrombosis and pulmonary embolism: common disease, rare complication. Respirol Case Rep 2014; 2:132-134.

10. IPPOLITO E, BUORA A, BELCARO G, ALARI G, ARPAIA G, CIAMMAICHELlA G. Deep vein thrombosis and pulmonary embolism in a patient affected by uterine fibroids: clinical case. Panminerva Med 2012; 54:97-99.

11. KHADEMVATANI $\mathrm{K}$, REZAEI $\mathrm{Y}$, KERACHIAN A, SEYYED-MOHAMMADZAD MH, ESKANDARI R, ROSTAMZADEH A. Acute pulmonary embolism caused by enlarged uterine leiomyoma: a rare presentation. Am J Case Rep 2014; 15:300-303.

12. PAKIZ M, BUT I. Management of acute deep vein thrombosis due to enlarged symptomatic uterine fibroids. Int J Gynaecol Obstet 2009; 105:177-178.

13. PODDUTURI V, ARMSTRONG-BRILEY DR, GUILEYARDO JM. Sudden death by pulmonary thromboembolism due to a large uterine leiomyoma with a parasitic vein to the mesentery. Case Rep Obstet Gynecol 2014; 2014:181265. 
14. ROSENFELD H, BYARD RW. Lower extremity deep venous thrombosis with fatal pulmonary thromboembolism caused by benign pelvic space-occupying lesions - an overview. J Forensic Sci 2012; 57:665-668.

15. SRETTABUNJONG S. Systemic thromboembolism after deep vein thrombosis caused by uterine myomas. Am J Forensic Med Pathol 2013; 34:207-209.

16. BARSAM S, BAGOT C, PATEL R, SIDHU PS, DAVIES A, ARYA R. Extrinsic venous compression: a sufficient explanation for venous thromboembolism due to massive fibroids? Thromb Haemost 2006; 96:694-696.

17. NELSON AL, RITCHIE JJ. Severe anemia from heavy menstrual bleeding requires heightened attention. Am J Obstet Gynecol 2015; 213:97-6.

18. RAJASEKHAR A. Inferior vena cava filters: current best practices. J Thromb Thrombolysis 2015; 39:315-327.

Received July 8, 2015 